\title{
Kemiskinan Perkotaan
}

Shohibul Anshor Siregar

I Kemiskinan perkotaan hanyalah sebuah fakta tentang betapa keadilan tak dikenali oleh dunia karena brutalitas kapitalisme dan neoliberalisme yang sangat ganas | Boleh saja ada pemerintahan di kolong langit yang sambil berneoliberasi ria sekaligus meneriakkan keadilan dan pemberian affirmative action membela kaum lemah korban keadilan yang miskin di perkotaan itu |

Jika ingin fair dan tuntas, masalah kemiskinan perkotaan sebagai kondisi perwilayahan tertentu tidak boleh dipisahkan dari kemiskinan wilayah lainnya, yakni kemiskinan perdesaan. Secara akademik interdependensi antara keduanya tidak mungkin ditolak. Perkotaan dan perdesaan adalah sebuah kontinum belaka. Meski banyak sarjana yang sangat berhasil menunjukkan karakteristik yang berbeda antara perkotaan dan perdesaan, dan malah dalam rencana studi di perguruan tinggi tak jarang dibagi menjadi dua kajian mata kuliah yang berbeda, namun hal itu tidak membantah hubungan interdependensi keduanya.

Ketika membicarakan urbanisasi, misalnya, sangat tidak memuaskan jika sekadar memberi penjelasan ekonomis, sosiologis, politis dan kultural, tentang berbondongnya migrasi penduduk dari perdesaan ke perkotaan karena fenomena itu pun secara bersamaan juga menimbulkan fenomena ruralisasi di daerah urban. Belakangan ini dengan amat lucu para elit politik nasional menghembuskan urgensi pemindahan ibukota negara dari Jakarta ke tempat lain. Mereka lupa selama gula hanya ditumpukkan di sebuah tempat yang bernama kota (ibu kota), maka secara naluriah semut pasti akan berbondong tak terkendali dari semua penjuru desa (keterbelakangan).

Kemiskinan adalah ketimpangan (inequality) yang penyebabnya tidak mungkin dicari hanya pada diri, komunitas dan lokasi permukiman orang miskin, karena kemiskinan tidak hadir sebagai atribut orang-orang yang otomatis selesai jika orang miskin itu sendiri, misalnya, dibentak "kerja, kerjakerja". David C McLelland (1988) adalah salah seorang pelopor yang ingin menjelaskan fenomena kemiskinan dari aspek psikologis dan di ujung narasinya menyarankan pengembangan pribadi karena secara psikologis manusia itu memiliki apa yang disebut dengan Need for Achievement. Teori ini sama sekali tak menjelaskan mengapa ketimpangan selalu melekat pada struktur sosial lokal, nasional dan global sepanjang masa dan mengapa kemiskinan tak mungkin direduksi tanpa pendekatan komprehentif.

Ketimpangan itu sepintas hanyalah masalah ekonomi, tetapi sesungguhnya tidak bisa dilepas dari sejarah dan politik yang berusia sangat panjang. Dengan latar belakang seperti itu, maka segera dengan mudah dapat diidentifikasi pola-pola usaha mereduksi kemiskinan. Ketimpangan adalah interaksi yang dihasilkan oleh tiga jenis transaksi, yakni transaksi buruh dengan majikan, transaksi daerah dengan pusat, dan transaksi negara dengan multinational corporations atau interaksi Negara miskin (yang selamanya berlangsung eksploitatif) dengan negara kaya.

Keseluruhan interaksi itu berlangsung asimetris. Asimetris interaksi itu bermacam pola. Bahkan apa yang disebut dengan pinjaman (loan), hibah (grant) dan bantuan (aid) adalah hal-hal yang kerap djadikan selimut hegemoni yang bertujuan mengekalkan eksploitasi negara kaya terhadap negara miskin. Celakanya, mainstream pandangan dunia berikut instrumen hukum dan diplomasinya selalu melegitimasi. Program dunia berupa MDGs dan yang dilanjutkan dengan SDGS mengacu pada sebuah kesadaran global atas fakta kesenjangan. Tetapi teriakan-teriakan moral seperti itu tidak mungkin mengubah paradigma global untuk berbelaskasih kepada yang miskin. Neoliberalisasi yang menjadi pilihan dunia meniscayakan ketidak-mungkinannya tercapai. Pertemuan kota sedunia yang diselenggarakan bulan lalu di Kuala Lumpur juga tidak lepas dari permasalahan yang sama. 
Karena itu strategi pembahasan, sekali lagi jika ingin fair dan tuntas, tentang usaha-usaha menanggulangi kemiskinan seyogyanya tidak melokalisasi masalah menjadi atribut orang miskin dan atribut serta situasi sosial lokal secara independen yang menjuruskan kajian-kajian sia-sia atas faktafakta sosial slum area di kota dan cultural lag lainnya. Cultural lag adalah situasi dan kondisi kontras yang mendeskripsikan kesenjangan yang membuktikan distribusi sumberdaya dan kesempatan selalu gagal dilakukan dalam kebanggaan negara dan pelaku dunia usaha mengejar pertumbuhan (growth).

Rekomendasi badan-badan dunia belakangan selalu dihiasi dengan isyu-isyu seperti itu meski tak pernah berimplikasi kebijakan yang mendasar. Pemukiman-pemukiman kumuh yang oleh banyak pemerintahan kota di dunia lazim dianggap sebagai noktah yang memperburuk tampilan dan citra, sehingga mereka ingin dimusnahkan saja dengan mobilisasi kekuatan negara. Kajian harus didasarkan pada paradigma lengkap historis, politik, ekonomi dan kondisi struktural yang menindas.

Seyogya negara, di mana pun juga, tak boleh berhenti pada masalah-masalah simptomik belaka. Akar permasalahan kesenjangan global ada pada hasrat penguasaan materi dengan berbagai cara yang belakangan kita sebut penjajahan. Sebuah negeri kepulauan yang belakangan disebut Indonesia adalah kerjaan-kerajaan Islam yang kaya raya, dan sebelumnya di sana tercatat keunggulankeunggulan peradaban. Itu sebelum kehadiran para penakluk dengan amunisinya.

Indonesia yang aman damai tak memiliki sifat ekspansionisme (penjajahan), dan nasibnya begitu menyedihkan setelah kedatangan para penjajah yang mempergilirkan Indonesia dari satu ke lain situasi yang sangat sulit.Sejak berakhirnya Perang Dunia Kedua memang reformulasi tata dunia dihadirkan dengan antara lain munculnya dan meguatnya negara-negara nasional baru yang sengaja dilepas atau berhasil melepaskan diri dari penjajahan.

Masih ingat Kisah konferensi Meja Bundar? Betapa malangnya nasib negeri yang dijajah 350 tahu dipaksa membayar kerugian negara penjajah sedangkan kerugian bangsa terjajah tidak pernah mendapat agenda pembicaraan? Jepang saja yang menduduki (bukan menjajah) memberi pampasan kepada Indonesia yang karena jumlahnya cukup besar dibayar cicil selama 12 tahun. Kini dunia rajin mengkampanyekan anti teroris, padahal akarnya ada pada ketidak-adilan dan haus darah negaranegara besar. Nasib pengungsi yang begitu menyedihkan hanya menghiasi sudut-sudut kecil pemberitaan dunia yang dikalahkan oleh berita remeh-temeh seperti adanya seorang pemimpin yang masuk got untuk memeriksa tiga lembar daun yang menyumbat gorong-gorong.

Tetapi tata dunia tak saja dibuat tetap memelihara hak-hak istimewa negara besar yang setiap hari semakin hegemonik. Konferensi Asia-Afrika yang monumental itu adalah sebuah gerakan perlawanan besar atas hegemoni. Ketika Bung Karno mencetuskan doktrin Trisakti (Kedaulatan Politik, Berdikari dalam Ekonomi, dan Kemandirian sosial Budaya), jelas perlawanannya terhadap neokolonialisme sebagai segala-galanya.

Tetapi rezim-rezim developmentalisme yang saling mempergilirkan kekuasaan di Indonesia menghendaki ketergantungan selama-lamanya.Ini tidak saja tercermin dari organisasi seperti PBB, instrumen-instrumen lain yang dibentuk kemudian seperti IMF dan lain-lain, semuanya tidak terlepas dari upaya-upaya sistematis untuk melegalisasi hak-hak istimewa negara-negara besar. Kesepakatan-kesepakatan internasional dan multinational lainnya juga tidak terlepas dari upaya memelihara hegemoni itu.

Agaknya sejak sekitar tahun 1970-an kelihatan PBB mulai membicarakan masalah-masalah serius tentang persamaan hak. Namun tidak pernah menyintuh hal substantif. Konon Karibia memulai dengan tuntutan reparasi atas negara-negara eks jajahan dari negara penjajahnya. Pelanggaran HAM 
yang tak akan pernah termakan waktu (kedalwarsa) dijadikan alasan untuk memulihkan hak-hak mereka yang pernah dinistakan atas nama kekuasaan dan haus darah.

Tetapi tuntutan itu tidak pernah masuk sebagai isyu untuk diagendakan dalam pembicaraan PBB. Orang di Indonesia masih belum sadar betapa hantaman pasar bebas ASEAN itu malapetaka. Arus barang dan jasa secara bebas menghantam orang-orang tak berdaya. Padahal konstitusi mengatakan bahwa negara dibentuk untuk melindungi segenap tumpah darah. Bagaimana rezim bisa berfikir seperti menyerahkan Indonesia menjadi mangsa bagi bangsa lain yang HDI-nya jauh di atas bangsa sendiri?

Kita ingin meringkas uraian tentang perjalanan sejarah yang buruk ini. Para pemimpin pemerintahan di seluruh dunia dan lembaga pemangku kepentingan lainnya, begitu disebut oleh sebuah dokumen, dalam memasuki tahun 2018 kelihatannya langsung berhadapan dengan serangkaian masalah yang semakin sulit dan semakin mendesak, di antaranya ekonomi dunia yang menghadapi periode yang berlarut-larut dalam pertumbuhan yang relatif rendah. Juga makroekonomi dan demografi yang kelihatannya akan menentukan takdir ekonomi dunia pada masa yang akan datang. Bukankan semua berhadapan dengan ruang fiskal yang terbatas, tingkat suku bunga mendekati nol, dan tren demografis yang tidak menguntungkan di banyak negara?

Hal lain yang mencemaskan dunia memasuki tahun 2018 ialah pertanyaan "dapatkah ketimpangan di dalam negara meningkat secara memuaskan dalam tatanan ekonomi internasional liberal yang berlaku? Dapatkah semua perkembangan yang terjadi dianggap sebagai bukti kuat atas kesalahan pendapat yang dianut secara kuat selama ini bahwa ekonomi kapitalis modern menghadapi keterbatasan yang melekat dalam hal ini bahwa sistem distribusi pendapatan "internal mereka" rusak dan kemungkinan tidak dapat diperbaiki?

Seiring meningkatnya gangguan teknologi dalam Revolusi Industri Keempat, bagaimana masyarakat dapat mengatur diri mereka dengan lebih baik untuk menanggapi potensi kerja dan efek distribusi lainnya? Apakah pembayaran transfer diperluas menjadi satu-satunya solusi utama, atau mekanisme pasar dapat dikembangkan untuk memperluas partisipasi sosial dalam bentuk penciptaan nilai ekonomi baru?

Seluruh pertanyaan itu memunculkan pertanyaan yang lebih mendasar tentang apakah koreksi sekuler diperlukan dalam model pertumbuhan ekonomi yang ada untuk menangkal stagnasi dan penyebaran sekuler (pertumbuhan rendah kronis dan meningkatnya ketidaksetaraan). Apakah peta mental tentang bagaimana pembuat kebijakan mengkonseptualisasikan dan memungkinkan kinerja ekonomi nasional perlu digambar ulang? Apakah ada cara struktural, di luar ukuran moneter dan fiskal sementara beberapa tahun terakhir, untuk memotong simpul Gordian dalam pertumbuhan yang lambat dan ketidaksetaraan yang meningkat, untuk mengubah lingkaran setan saat ini dari stagnasi dan penyebaran menjadi inklusif dan pertumbuhan yang lebih berkelanjutan saling memperkuat satu sama lain?

Agaknya inilah yang pemerintah, bisnis, dan pemimpin lainnya dari setiap daerah terus-menerus dicari solusinya. Tidak dapat dibantah bahwa selama beberapa tahun terakhir, sebuah konsensus di seluruh dunia telah muncul mengenai kebutuhan akan model pertumbuhan dan pengembangan yang lebih inklusif. Pertumbuhan inklusif tetap menjadi topik diskusi daripada agenda aksi. Siapa pun tak pernah tercerahkan nasibnya dari diskusi yang menghabiskan banyak energi, waktu dan biaya ini.

Kemiskinan perkotaan hanyalah sebuah fakta tentang betapa keadilan tak dikenali oleh dunia karena brutalitas kapitalisme dan neoliberalisme yang sangat ganas. Boleh saja ada pemerintahan di kolong langit yang sambil berneoliberasi ria sekaligus meneriakkan keadilan dan pemberian affirmative 
action membela kaum lemah korban keadilan yang miskin di perkotaan itu. Tetapi jangan pernah berhenti bersedekah, berinfaq dan berzakat, karena di sana penegasan imperatif tentang kewajiban sesama dianggap menjadi bagian dari kemanusiaan yang tak boleh hanya didengungkan tanpa regulasi yang membantu dunia keluar dari kesulitan ini.

Shohibul Anshor Siregar Naskah ini pertamakali diterbitkan oleh Harian WASPADA

Medan, Senin, 26 Maret 2018, hlm B7 